\title{
Introduction to the Symposium: Lessons from Detroit
}

\author{
Karyn Lacy* \\ University of Michigan, Ann Arbor
}

In 2014, Detroit was ranked 8th on a list of the country's 10 unhappiest cities. Despite its glorious past, the city is now in deep trouble. Four phenomena contributed to Detroit's placement on the list and set Detroit apart from other large American cities.

First, Detroit has too much land and too few residents. The city stretches over 139 square miles. Detroit is vast. And when a sprawling city loses more than 60 percent of its population, such a mass exodus leads to other problems. In its heyday, Detroit was teeming with people. In 1950, the population was 1.85 million. By 1990, the population had dwindled to 1.2 million. And today, less than a million people, only about 714,000 , are rattling around the city. Detroit is empty. And that means unlike New York or San Francisco, where finding even a tiny square to park your car is an ordeal, in Detroit, land is plentiful and affordable. Developers need not build up, they can spread out. Housing is dirt-cheap. You can buy a house in Detroit for $\$ 25,000$. Today, many blocks in Detroit are home to a single family, living amid a sea of unoccupied, boarded up homes. The city struggles to provide basic services-trash pickup, water, electricity, and police and fire protection-to these isolated homeowners. As a result, Detroit's tax rate is way too high, especially given the sketchy services homeowners receive in return. A core assumption of urban sociology is that cities grow, and growth is a clear signal that a city is thriving. But Detroit is not growing, it is shrinking, posing a new set of challenges for urban scholars and planners. The path forward for the city is much debated among scholars, practitioners, and residents alike, with supporters insisting, "To grow Detroit, you have to shrink Detroit!"

Second, Detroit is stigmatized as a crime ridden, undesirable place to live, in part because of a large black presence: The city is 87 percent black. About 30 percent of residents live in poverty. Only 38 percent of Detroit residents are employed within the city's boundaries, as opposed to the suburbs. There is virtually no real demand for housing apart from investors hoping to flip foreclosed homes and make a quick buck. Gentrification is under way in only a few select neighborhoods. We know from Reynolds Farley's attitudinal studies of neighborhood preferences that most whites are not willing to live in a city like Detroit. The influx of young college graduates, artists, and entrepreneurs is a hopeful sign, but scholars disagree as to whether the presence of these special interest groups will revive Detroit.

Third, Detroit is not known for its amenities. A return migration from the suburbs back to the city is underway in many metropolitan areas around the country as empty nesters, bored with the placid suburban life they once valued back when they had children living

\footnotetext{
*Correspondence should be addressed to Karyn Lacy, Department of Sociology, 500 S State Street, University
} of Michigan, Ann Arbor 48104; krlacy@umich.edu.

City E Community 14:2 June 2015

doi: $10.1111 /$ cico. 12100

(C) 2015 American Sociological Association, 1430 K Street NW, Washington, DC 20005 
at home, now seek walkable communities with a broad selection of restaurants, shopping, and the arts. Edward Glaeser along with his coauthors Jed Kolko and Albert Saiz coined the term "consumer cities" to refer to cities organized around consumption rather than production. Detroit is not that place. It is a one-industry town struggling to remake itself in the wake of the demise of the auto industry.

Finally, and perhaps most importantly to the authors contributing to this symposium, Detroit is a city wrestling with its earlier commitment to decentralization. In 1974, the city established a charter granting community councils the power to weigh in and shape policy, including urban renewal, planning and zoning decisions, crime prevention, and so on. Some argue that, once community councils took root the city government abdicated its responsibility to its citizens. Others welcome the activist agendas of residents and the potential for regional cooperation with Detroit's suburban neighbors. The articles included in this symposium contribute, either directly or indirectly, to the ongoing debate about the long-term impact of decentralization.

Peter Eisinger's article picks up where his 2003 City $\mathcal{E}$ Community article left off. There, Eisinger argued that while political elites and developers attempt to reinvent Detroit by circumventing the city's legacy as an industrial powerhouse characterized by pervasive racial residential segregation, the development models they propose instead-Detroit as a world-class city, as a tourist destination, or as the economic hub for the metropolitan area-are all so quixotic as to be unattainable. To claim that Detroit is poised to become "one of the world's premier cities" in the face of consistent evidence to the contrary, he argued, strains credibility and undermines the public's trust in their elected officials. At the same time, reconstructing Detroit primarily as a destination for tourists or suburbanites risks alienating the city's residents, whose economic and political interests differ substantially from those of outsiders. Eisinger's article in this issue reassesses his 2003 critique in the aftermath of the city's bankruptcy proceedings. Now more than ever, Detroit desperately needs a clear path forward. The three original development models for the city are still in play, but a fourth vision, Detroit as a destination for "urban pioneers," has emerged too as young artists and college graduates migrate to the city, lured by cheap rents and the entrepreneurial spirit that has taken root in the city. The urban pioneers model also includes the expansion of activism among older residents, who take the initiative to organize safety patrols in the absence of a dependable police presence, demolish boarded-up buildings that the city has long ignored, and create car-sharing networks as a substitute for Detroit's inefficient public transportation system. In Urban Fortunes, Logan and Molotch challenged the established view that economic growth is inherently good, suggesting instead that there are significant costs to development, benefitting some groups while oppressing others. In observing that each vision reinforces cleavages-race, class, tenure, and age - rather than uniting all the city's residents and neighborhoods under a common cause, Eisinger illuminates these costs in the Detroit context. Until these conflicts are resolved, Detroit will not recover.

Reynolds Farley's article also takes the 2013 bankruptcy of Detroit as a point of departure. To understand how Detroit became the largest city in the United States to file for bankruptcy, Farley assesses the role of race relative to other explanatory factors. Given Detroit's racially divisive history, many readers may assume that racial division is the primary cause of Detroit's economic collapse. Through historical analysis of the competition for neighborhoods, schools, and employment among black and white residents, Farley 
argues that the path to bankruptcy is rooted in a long history of invidious distinctions by race, but the more immediate factors are deindustrialization and suburbanization.

Some scholars and urban planners believe that regionalism-economic interdependence between Detroit's local government and suburban municipalities-is the best strategy to ensure Detroit's prosperity. Michael Indergaard's article examines the evidence buttressing this claim. While he notes that a few urban-suburban coalitions have formed in recent years, Indergaard questions whether regionalism will live up to its promise. For one thing, he shows that these alliances have been sustained in part through a combination of the carrot-incentives provided by foundations and federal agencies-and the stick-local judges ordering municipalities to cooperate. These alliances do represent a sea change compared to the 1974 Milliken Supreme Court decision upholding marked divisions between the Detroit public school system and its suburban school districts. Today, there is far more cooperation across municipal boundaries. But because they are blinded by the mere formation of these alliances, Indergaard posits that new regionalists underestimate the extent to which familiar divisions such as race and class, as well as emerging divisions such as uneven development, undermine regionalism in the metropolitan area. When the auto industry crashed, Detroit's diverse suburban communities did not experience these economic crises in the same way. In addition, Indergaard finds that the coalition's political elites tend to advance their own interests over and above those of disadvantaged groups. Resources distributed through these metropolitan area coalitions are concentrated in the communities that elites prefer to frequent, such as Detroit's Midtown and Downtown neighborhoods, rather than spread evenly throughout the city, a process that perpetuates inequities within the city's boundaries.

Rebecca Campbell's article coauthored with Jessica Shaw and Giannina Fehler-Cabral explores how and why Detroit's police department managed to amass more than 10,000 untested rape kits. At first blush, the article is not an obvious fit in a special issue focused on whether it is possible to revive Detroit. But, as Jane Addams explained, a city cannot solve major problems until it has a structure in place to ensure the safety and security of residents. With respect to sex offenses, Detroit is not yet safe. In too many U.S. cities, police departments have failed to routinely test rape kits, the most important evidence in the prosecution of individuals accused of rape. The problem is not unique to Detroit, but when combined with demographic data-extreme racial residential segregation, an escalating poverty rate, and in the 1990s, a ranking as the U.S. city with the highest rate of violent crime, Detroit stands out as a particularly egregious case of police negligence and misconduct regarding the prosecution of sex crimes. Rather than testing the rape kits, police officers stacked them in a storage room. Through in-depth interviews and analysis of memos circulated between police officers and prosecutors, Campbell, Shaw, and Fehler-Cabral find that police officers failed to take accusations of rape seriously in a city where victims are disproportionately black and poor. Both groups are less likely to be perceived as credible when they report a crime. The authors find police officers reasoned in their reports that victims were not really raped, invoking deep-seated stereotypes of black women as sexually available. Officers tended to assign rape victims the offensive label of "prostitute" and, operating under the equally misguided belief that prostitutes cannot be raped, declined to process their rape kits. Teenage victims were also dismissed as liars, as kids concocting stories about having been raped to avoid getting into trouble at home. Although the nation is currently fixated on Ferguson and Staten Island, notorious examples of police misconduct worthy of our attention, the authors show that police 
recalcitrance and unwillingness to admit wrongdoing are serious problems in sexual assault cases too. Detroit cannot prosper so long as the city's streets are unsafe. The city is only just beginning to resolve its rape kits problem after finally reversing course on the procedure for processing this evidence.

Laura Reese's article evaluates Detroit's inability to solve what has quickly become an enormous stray animal population problem. Reese observes that while scholars have studied the ways in which urbanization encroaches on the natural habitats of a region's wildlife, little is known about the conditions under which wild animals invade the central city, an inevitable outcome of urban sprawl. Detroit's economic collapse contributed to the sharp rise in stray animals, as unemployed and underemployed residents tend to abandon their pets. But Reese argues a struggling economy is not the only factor, indeed, it is not the primary factor. Instead, Detroit's decentralized governmental system is the root cause of the stray animal problem. Detroit's political leadership has not organized consistently or successfully to control a burgeoning stray animal population, a crisis affecting poor neighborhoods disproportionately. The Detroit Animal Control agency has a total of three licensed animal control officers. As a result, nonprofits have emerged to do the hard work that the city cannot. However, Detroit is isolated from the metropolitan area's animal welfare agencies. Through analysis of the service provisions of animal welfare organizations, Reese finds little evidence in support of regionalism. Detroit's leadership has minimal ties to suburban animal welfare organizations. These agencies, composed primarily of white women volunteers, share resources and volunteers among themselves, but they report minimal cooperation with Detroit's animal shelters.

Together these articles show that there is little consensus among residents, public officials, and community leaders about the best path forward for Detroit. The authors contributing to this issue hint that Detroit can be saved, but clearly any intervention should protect the interests of all of the city's residents. 